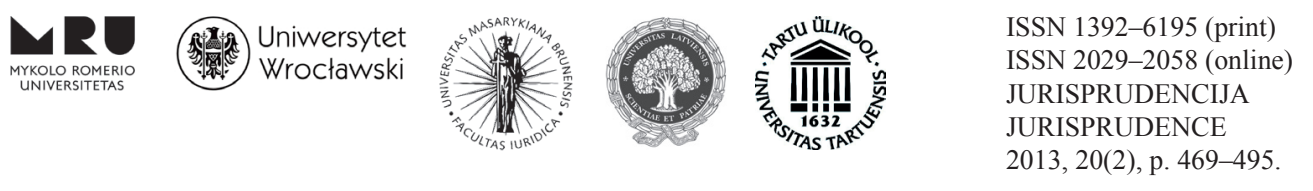

\title{
THE BINDING FORCE OF THE CASE LAW OF THE COURT OF JUSTICE OF THE EUROPEAN UNION
}

\author{
Gundega Mikelsone \\ University of Latvia, Faculty of Law, \\ Chair of Legal Theory and History \\ 19 Raina Blvd., LV-1586, Riga, Latvia \\ Advocate office „Centrs“ \\ Telephone: (+371) 26450188 \\ E-mail: Gundegai.Mikelsonei@gmail.com
}

Received on 26 May, 2013; accepted on 31 June, 2013

doi:10.13165/JUR-13-20-2-06

\begin{abstract}
The article is dedicated to determine de iure and de facto binding force of the case law of the Court of Justice of the European Union (hereinafter the ECJ) and its place in the system of legal sources in Latvia. The author concludes that the case law of the ECJ consists of legally important statements, which are included in judgements of the ECJ, namely, of an interpretation of legal norms, made by the ECJ, and of judge-made law norms, which the ECJ has found in legal system by use of a further law-making. Therefore, it follows from the above that the case law of the ECJ is regarded as binding independent addition legal source in Latvia. This publication concerns not only Latvia, but also other European Union (hereinafter the EU) member states of the continental Europe or Romano-Germanic legal system.
\end{abstract}

Keywords: the Court of Justice of the European Union, case law, judge-made law, legal sources, interpretation, further law-making. 


\section{Introduction}

Starting from accession of the Republic of Latvia to the EU on 1 May 2004, EU law has become a part of the national legal order. The EU law is composed of not only regulatory acts and general principles of law, but also of the judgements and the case law included in the judgements made by courts of this organization, especially the ECJ ${ }^{1}$ as the major representative of the judiciary in the $\mathrm{EU}^{2}{ }^{3}$ The case law of the ECJ is formed from legally important statements consisting of interpretation of legal provisions made by the ECJ and judge-made law found through further law-making. According to the legal doctrine, today the ECJ is one of the most influential courts in the world that has deeply and broadly made an impact on the overall European integration, and its judgements have crucially affected different political areas. ${ }^{4}$ Therefore, it is important to ascertain de iure and de facto binding force of the case law of this court and to determine its place in the national system of legal sources. ${ }^{5}$

In order to determine the de iure status of the case law of the ECJ, all legal acts of the EU and Latvia (both regulatory acts and acts regarding application of law) pertaining to the regulation of this issue should be considered. It is also important to ascertain the opinions of legal scientists and how the persons applying the law in Latvia and the ECJ itself refer to the case law of this court, namely its de facto binding force and its place in the national system of legal sources. This publication concerns not only Latvia, but also other EU member states of the continental Europe or Romano-Germanic legal system.

The aim of the study is to determine de iure and de facto binding force of the case law of the ECJ and its place in the national system of legal sources, while the tasks of the research are as follows: to consider all legal acts (both regulatory acts and acts regarding application of law) regulating this issue and to ascertain the opinions of legal scientists and how the persons applying the law in Latvia and the ECJ itself refer to the case law of this court.

1 Following the entrance into force of the Treaty of Lisbon on 1 December 2009, the European Community was renamed the European Union and the Court of Justice of the European Communities - the European Court of Justice, therefore, within the framework of this work, only the new names have been used when referring to the European Community and the Court of Justice of the European Communities, except for quotations and names of historical legal acts. Treaty of Lisbon amending the Treaty on European Union and the Treaty establishing the European Community, OJ 2007 C 306/01.

2 Марченко, М.Н. Судебное правотворчество и судейское право. 2008, р. 445.

3 Constantinesco. The ECJ as a Law Maker: Praeter aut Contra Legem? in O'Keeffe, D. \& Bavasso, A. (eds.). Judicial Review in European Union Law. 2000, 73: 74.

4 Sweet. The European Court of Justice, in Craig, P. and de Búrca, G. (eds.). The Evolution of EU Law. 2nd edition. 2011, 121: 121.

5 All that has been written about the ECJ also refers to other EU courts - the General Court and specialised courts - as far as their competence is pertaining to the areas the power of a member state (consequently Latvia) may face, e.g., the competence of the General Court to make preliminary rulings (see Article 19, paragraph 1 of the Treaty on European Union; Article 254, Article 256, paragraph 3 and Article 257 of the Treaty on the Functioning of the European Union). Treaty on European Union (consolidated), OJ 2010C 83; Treaty on the Functioning of the European Union (consolidated), OJ 2010 C 83; see also: Craig, P. and de Búrca, G. EU Law. Text, Cases, and Materials. $5^{\text {th }}$ edition. 2011, p. 109. 
The study includes the use of the comparative, systemic, inductive, deductive and historical methods. The comparative method has been adopted for comparing opinions of legal scientists; the systemic method has been employed for the systemic interpretation of the EU provisions; the inductive and deductive methods have been used for separating the interpretation from the further law-making, whereas the historical method has been employed for the historical study of EU law.

In the first part of the study entitled 'The Binding Force of the Case Law of the ECJ - Opinions of Legal Scientists' the author analyses the opinions of legal scientists on the binding force of the case law of the ECJ. The second part called 'Why the Case Law of the ECJ is Binding Independent Additional Legal Source in Latvia' presents arguments why the case law of this court should be recognized as binding independent additional legal source in Latvia. The third part of the study entitled 'Binding Case Law rather than the Judge-Made Law (Binding Precedents)' answers the question whether the ECJ creates the judge-made law (binding precedents) or binding case law.

'It results from the case-law of the Court of Justice that
primacy of EC law is a cornerstone principle of Community law.
According to the Court, this principle is inherent to the
specific nature of the European Community.
At the time of the first judgment of this established case law
(Costa/ENEL, 15 July 1964 , Case 6/641) there was no mention
of primacy in the treaty. It is still the case today.
The fact that the principle of primacy will not be included
in the future treaty shall not in any way change the existence
of the principle and the existing case-law of the Court of Justice.

\section{The Binding Force of the Case Law of the ECJ - Opinions of Legal Scientists}

The binding force of the case law of the ECJ and its place in the national system of legal sources have not been broadly and deeply investigated either in Latvia or in other countries, and different views have been expressed about this issue. Even in the beginning of the 21 st century, German legal scientist and sworn advocate Dr. iur. Donat Ebert ${ }^{7}$ recognized that the direct binding force erga omnes of the judgements of the ECJ has not still been clarified. ${ }^{8}$

Closer attention has been given to the methods for application of law used by the ECJ. This court has regularly been criticized for being too involved in further law-

6 Declaration concerning primacy: Declarations, annexed to the Final Act of the Intergovernmental Conference which adopted the Treaty of Lisbon, signed on 13 December 2007, OJ 2007 C 306/02.

7 Lutere-Timmele. Priekšvārds, in Lutere-Timmele, D.L. (scient. ed.). Eiropas Savienības Tiesību Piemērošana. Rokasgrāmata Praktizējošiem jJuristiem. Otrais Papildinātais Izdevums. 2008, 13: 14, 15.

8 Eberts. Eiropas Tiesības Latvijas Tiesu Praksē. Ievads Eiropas Tiesībās, in Lutere-Timmele, D.L. (scient. ed.). Eiropas Savien̄̄bas Tiesību Piemērošana. Rokasgrāmata Praktizējošiem Juristiem. Otrais Papildinātais Izdevums. 2008, 19: 25. 
making, thus, occupying the role of the legislator not provided by the EU founding Treaties and shifting the balance between the branches of power. It is argued that the ECJ, through its judge-made law, creates new primary ${ }^{9}$ EU law, invents artificial general principles of law, extends its competence and constantly subjects new branches of law to the EU law. This ECJ activity has often been described as judicial activism. ${ }^{10}$

The dominant view of Latvian legal scientists is that the case law of the ECJ must be taken into consideration ${ }^{11}$. However, there are other opinions as well, such as that the case law of the ECJ 'completely refers' to Latvia ${ }^{12}$; it is binding not only on national courts, but also on any public institutions engaged in application of the EU legal provisions and on the legislator in order to ensure that the national legal acts comply with the EU law ${ }^{13}$; it is impossible to correctly adopt and establish the EU legal acts without any explanatory additional material resulting from the judge-made law ${ }^{14}$ and that Latvian judges are bound by the case law of the institutions of the EU courts ${ }^{15}$. Unfortunately, authors making these statements have not revealed their content. Along with the above-mentioned opinions, the legal doctrine includes direct references to the

9 The EU founding Treaties with later additions and amendments, namely the Treaties of Maastricht, Amsterdam, Nice and Lisbon, as well as the various Accession Treaties with the annexes, appendices and protocols attached to them, contain the basic provisions on the EU's objectives, organisation and modus operandi and parts of its economic law. They thus set the constitutional framework for the life of the EU, which is then fleshed out in the EU's interest by legislative and administrative action by the EU institutions. These provisions, being legal instruments created directly by the Member States, are known in legal circles as primary Union law. Borharts, K.D. Eiropas Savienības Tiesību Ceļvedis. 2011, p. 78-79 [interactive]. [accessed on 08-08-2012]. <http://eur-lex.europa.eu/lv/editorial/abc.pdf >. See also: Latvijas Republikas Tieslietu Ministrija. Eiropas Savienības Tiesību Ieviešanas Rokasgrāmata. 2008, p. 6-7 [interactive]. [accessed on 08-08-2012]. <http://www.tm.gov.lv/lv/daliba_es/es_ta/tm_kompetence. html>.

General principles of law also belong to the EU's primary law. Borkoveca, M. Dalībvalstu Tiesību Normu un Eiropas Savienības Tiesību Normu Kolīziju Risināšanas Problēmjautājumi. Doctoral Thesis, Latvia, Riga, p. 62 [interactive]. [accessed on 10-08-2012]. <https://luis.lanet.lv/pls/pub/luj. fprnt?1=1\&fn=F1235036252/Marina\%20Borkoveca\%202011.pdf $>$.

10 See, for instance, Pierhuroviča. Eiropas Savienības Tiesas Juridiskais Aktīvisms. Jurista Vārds. 2010,30 (625); Herzog and Gerken. Stop the European Court of Justice. Opinion.. 9 October, 2008 [interactive]. [accessed on 04-08-2012]. <http://euobserver.com/opinion/26714>; Nourissat. La Jurisprudence de la Cour de Justice des Communautés Européennes: Un Regard Privatiste à Partir de 1'Actualité. La Création du Droit Par le Juge. 2007, 245: 247, 254-259; Amos, M. Rule of Law or Judicial ActivismTwo Perspectives on the European Court of Justice. Master Thesis, Sweden [interactive]. [accessed on 04-08-2012]. < $\quad$ http://lup.lub.lu.se/luur/download?func=downloadFile\&recordOId=1554673\&fileO $\mathrm{Id}=1563405>$.

11 See, for instance, Dupate, K. Eiropas Savienības Tiesas Prakse Darba Tiesībās. 2011, p. 10 [interactive]. [accessed on 08-08-2012]. <http://www.lbas.1v/upload/stuff/201112/es_tiesas_prakse_darba_tiesibas. pdf $>$.

12 Ostrovska. Ārējo Normatīvo Tiesību Aktu Hierarhija Pēc Latvijas Pievienošanās Eiropas Savienībai (II). Likums un Tiesības. 2006, 3 (8): 73, 75, 79.

13 Latvijas Republikas Tieslietu Ministrija, supra note 9, p. 9.

14 Harbaceviča. Eiropas Savienības Tiesību Ieviešana Latvijā, in Alehno, I. (scient. ed.) et al. Eiropas Savienības Tiesību īstenošana Latvijā. 2003, 13: 22.

15 Levits. Judikatūra - Pamati, Problēmas, Piemērošana. Latvijas Republikas Augstākās Tiesas Biļetens. 2010, 1 (32): 34 . 
preliminary rulings made by the ECJ as a universally binding legal source in all the EU member states. ${ }^{16}$

In Latvia, most attention to the binding force of the case law of the ECJ has been given by Dr. iur. Ginta Sniedzīte in her Doctoral Thesis entitled 'Concept of JudgeMade Law, its Evolution and Role within Latvian Legal Doctrine of Sources of Law'. It concludes that the judge-made law of the ECJ has all characteristics of a binding provision and its source, i.e. the case law of the ECJ, and that it should be recognized as an independent legal source. However, Appendix 1 'System of Legal Sources', which illustrates this system, shows the case law of the ECJ among obligatory legal sources rather than the independent ones. ${ }^{17}$

Professor of the University of Latvia, Faculty of Law, Dr. iur. Daiga Rezevska considers that the case law of the ECJ should be placed into the group of independent additional legal sources along with other binding unwritten legal sources, which has also been shown in the diagram of the legal sources included in the slides for the Conference called 'The Case Law of the Supreme Court and its Role in the Development of Legal Thought in Latvia'. ${ }^{18}$

The binding force of the case law of the ECJ has indirectly been recognized by other authors as well, comparing its importance and impact to the EU regulatory acts of different legal force. French legal doctrine has suggested that legal provisions regulating the preliminary ruling proceedings can be found in Article 234 of the Treaty establishing the European Community ${ }^{19}$ and the case law of the ECJ relating to it. ${ }^{20}$ Vlad Constantinesco has concluded that according to many significant ECJ rulings, the EU law consists of not only regulatory acts, but also of judge-made law and the ECJ creates the EU law on the constitutional level. ${ }^{21}$ Latvian scientists agree with this opinion, indicating that the subject-matter of the question referred for a preliminary ruling is established by the main treaties, separate other documents and the case law of the ECJ.22 German legal scientists in turn have considered that 'there is general unanimity that

16 See, for instance, Freija; Lutere-Timmele and Vasarinšs. Prejudiciālais Nolēmums, in Lutere-Timmele, D.L. (scient. ed.). Eiropas Savienības Tiesību Piemērošana. Rokasgrāmata PraktizējošiemJjuristiem. Otrais Papildinātais Izdevums. 2008, 78: 93, 94, 138.

17 Sniedzīte, G. Tiesnešu Tiesību Jēdziens, Evolūcija un Nozīme Latvijas Tiesību Avotu Doktrīnā. Doctoral Thesis, Latvia, Riga, p. 61-68, 249, 286 [interactive]. [accessed on 03-08-2012]. <https://luis.lanet.lv/pls/ pub/luj.fprnt?l=1\&fn=F372913737/Ginta\%20Sniedzite\%202010.pdf $>$.

18 Rezevska. Judikatūra kā Tiesību Avots: Izpratne un Pielietošana. Latvijas Republikas Augstākās Tiesas Biletens. 2010, 1 (28): 31; Rezevska. Judikatūra kā Tiesību Avots: Izpratne un Pielietošana. Slides for the international conference dedicated to the 15th anniversary of operation of the Senate and Chambers of the Supreme Court. The Case Law of the Supreme Court and its Role in the Development of Legal Thought in Latvia. [interactive]. [accessed on 08-08-2012]. <http://www.at.gov.lv/lv/about/conferences/judic/>.

19 Treaty establishing the European Community (consolidated), OJ 2006C 321.

20 Naômé, C. Le Renvoi Préjudiciel en Droit Européen. Guide Pratique. 2007, p. 38.

21 Constantinesco, supra note 3, p. 74, 77. The ECJ has concluded that the EU Constitution consists of the EU founding Treaties. Case 294/83, Parti écologiste 'Les Verts' v. European Parliament, [1986] ECR 01339, para. 23. In legal science, this conclusion has been regarded as 'constitutionalizaton' of the EU treaties system made by the ECJ. Sweet, supra note 4, p. 130.

22 Freija; Lutere-Timmele and Vasariňš, supra note 16, p. 86. 
the courts of last instance should base their judgements on previous judgements of the ECJ, unless they decide to once again make application to the Court of Justice of the European Communities due to change in circumstances' ${ }^{23}$

\section{Why the Case Law of the ECJ is Binding Independent Additional Legal Source in Latvia}

The author agrees with Daiga Rezevska that the case law of the ECJ is binding independent additional legal source in the legal system of Latvia and regards that the legal basis of this opinion can be found in different legal sources, i.e. in EU regulatory acts, judgements and decisions of the ECJ and the Latvian courts and legal doctrine.

\subsection{Declaration concerning Primacy}

The author considers that following the entrance into force of the Declaration concerning primacy (hereinafter the Declaration) annexed to the Final Act of the Intergovernmental Conference, which adopted the Treaty of Lisbon on 1 December 2009 , there is no doubt that the case law of the ECJ belongs to the binding legal sources. Such status has been given (de facto - accepted) to this case law by the Declaration adopted by the member states together with the Treaty of Lisbon. The Declaration states that the general principles of law and their concretization included in the case law of the ECJ are binding legal provisions, regardless of whether they are written in any of the EU regulatory acts, including the EU founding treaties. Thus, the main legislator of the EU, i.e. totality of the member states, has accepted one of the most criticized operations of the ECJ, namely the invention of general principles of law, and has recognized the general principles of law and their concretization included in the case law of the ECJ as binding legal provisions.

Different views have been expressed on the legal status of the declarations attached to the EU founding Treaties. Professor Trevor Hartley suggests that the status of the declarations attached to the EU founding Treaties is not completely clear, for many of them have only political importance, while others in turn cause legal consequences. ${ }^{24}$ Another source of literature claims that declarations, in contradistinction to protocols, are not legally binding, yet they may create a political impact accepted by all member states; some of the declarations adopted together with the Treaty of Lisbon apply to the issues of constitutional importance; the declarations can be taken into consideration by the ECJ when interpreting provisions of the Treaties they apply to, as far as this does not contradict these provisions. ${ }^{25}$ Therefore, it can be concluded that the binding force of the

23 Eberts, supra note 8, p. 25.

24 Hartley, T.C. The Foundations of European Community Law. 6th edition. 2007, p. 87.

25 House of Lords, Constitution Committee. European Union (Amendment) Bill and the Lisbon Treaty: Implications for the UK Constitution. 6th Report of Session 2007-08. 2008, p. 9 [interactive]. [accessed on 01-09-2012]. <http://www.publications.parliament.uk/pa/ld200708/ldselect/ldconst/84/84.pdf>. 
case law of the ECJ has currently been recognized at least as a statement of political will of the EU's main legislator.

\subsection{The Principle of Primacy of EU Law}

The principle of primacy of EU law has been established by the ECJ with its judgement of 15 July 1964 in the Case 6/64, Costa v. E.N.E.L. ${ }^{26}$, by drawing this principle ${ }^{27}$ from the 'letter and spirit' of the Treaty establishing the European Economic Community (hereinafter the TEEC). However, this idea can be traced back to previous ECJ judgements, i.e. the judgement of 5 February 1963 in the Case 26/62, Van Gend and $\operatorname{Loos}^{28}$, and the judgement of 16 December 1960 in the Case 6/60, Jean-E. Humblet v. Belgian State ${ }^{29}$.

In its later judgements, the ECJ has stated that the principle of primacy of EU law also refers to the constitutions of the member states. The judgement of 17 December 1970 in the Case 11/70, Internationale Handelsgesellschaft, says that the validity of an EU legal act or its effect within a member state cannot be affected by allegations, it runs counter to either fundamental rights as formulated by the constitution of that state or the principles of a national constitutional structure; respect for fundamental rights forms an integral part of the general principles of law protected by the ECJ and the protection of such rights, whilst inspired by the constitutional traditions common to the member states must be ensured within the framework of the structure and objectives of the EU. ${ }^{30}$

In legal doctrine the primacy is understood as an ability of an EU law to override a national law in cases of conflict. ${ }^{31}$ This primacy determines a rule for resolving conflict between the EU law and national law: such conflict should be resolved by giving the

26 Case 6/64, Flaminio Costa v. E.N.E.L., [1964] ECR 00585. The principle of primacy of EU law has been specified more explicitly in a later judgement of the ECJ. See: Case 106/77, Amministrazione delle Finanze dello Stato v. Simmenthal SpA, [1978] ECR 00629, para. 17, 18, 21-24.

27 General principles of law can be derived from the basic rule of the legal framework or other general principles of law or drawn from legal acts or the entire legal framework in general. Iljanova, D. Vispārējo Tiesību Principu Nozīme un Piemērošana. 2005, p. 117; Rezevska. Tiesiskās Pal̦āvības Principa Satura Konkretizācija un Attīstība Judikatūrā, in Politika un Tiesības. Tiesību un Juridiskās Prakses Ilgtspējīga Attīstība. Rakstu Krājums. Apvienotais Pasaules Latviešu Zinātnieku 3. Kongress un Letonikas 4. Kongress. 2012, 9: 10.

28 In this case, the ECJ concluded the following: the EU constitutes a new legal order of international law for the benefit of which the states have limited their sovereign rights, albeit within limited fields, and the subjects of which comprise not only the member states but also their nationals. Case 26/62, NV Algemene Transport- en Expeditie Onderneming van Gend \& Loos v. Netherlands Inland Revenue Administration, [1963] ECR 00001.

29 This judgement says the following: if the court finds that a legislative or administrative measure adopted by the authorities of a member state is contrary to EU law, that state is obliged to rescind the measure in question and to make reparation for any unlawful consequences thereof. Case 6/60, Jean-E. Humblet $v$. Belgian State, [1960] ECR 00559.

30 Case 11/70, Internationale Handelsgesellschaft mbH pret Einfuhr- und Vorratsstelle für Getreide und Futtermittel, [1970] ECR 01125, para. 3 and 4. See also: Case C-285/98, Tanja Kreil v. Bundesrepublik Deutschland, [2000] ECR I-00069, para. 5, 12, 32.

31 Borkoveca. Eiropas Savienības Tiesību Sistēmas Mijiedarbība ar Dalībvalstu Tiesību Sistēmām. Jurista Vārds, 2010, 13 (608). 
EU law precedence on the basis of priority of the EU law application. The primacy can also express itself differently, i.e. as an obligation of appropriate interpretation - an obligation of public institutions to interpret the conflicting national law in compliance with the EU law. ${ }^{32}$

In accordance with the case law of the ECJ, all EU law prevail over all national laws of the member states, regardless of whether a national legal provision has been adopted before or after an EU legal provision. However, the EU law neither renders the conflicting national provision invalid nor annuls it, this provision is simply not applicable to the specific case. ${ }^{33}$ Moreover, it should be taken into account that the doctrine of primacy of EU law remains two-dimensional. The first dimension consists of the theory of primacy developed by the ECJ, but the second, i.e. its complete acceptance by the member states, depends on whether this doctrine will be included in the constitutional order of the member states and accepted by national high courts. ${ }^{34}$

The Constitutional Court of the Republic of Latvia (hereinafter the Constitutional Court) and the majority of Latvian legal scientists have fully accepted that the principle of primacy of EU law relates to all national written provisions, except the Constitution or Satversme of the Republic of Latvia ${ }^{35}$ (hereinafter the Constitution of Latvia), but does not relate to the constitutional fundamental provisions of the state or the core of the Constitution of Latvia. ${ }^{36}$ Content of the core of the Constitution of Latvia has been described by the Commission on Constitutional Law in its opinion of 17 September 2012 entitled 'On the Constitutional Basis of Latvian State and the Inviolable Core of the Constitution'. The said Commission has concluded that, for the material purpose, the core of the Constitution of Latvia is totality of the elements creating the constitutional identity of the Latvian State, while, for the procedural purpose, it is protection (inviolability) of the constitutional identity of the Latvian State. The constitutional identity is formed of the identity of the Latvian State (Latvia as a national state, a territory, people, and a sovereign state power of the Latvian State) and of the identity of the political system of the Latvian State (modern European (Western) democratic state, basic principles of a democratic state, a judicial state, a socially responsible state and a national state). ${ }^{37}$

Views on the relations between the EU law and the rest of the Constitutional provisions slightly differ. Latvian lawyer Linda Ostrovska considers that the principle

32 Borkoveca, supra note 9, p. 99, 101-102, 105.

33 Craig and Búrca, supra note 5, p. 266-267; Borkoveca, supra note 9, p. 62.

34 Craig and Búrca, supra note 5, p. 267-268.

35 Latvijas Republikas Satversme: the Constitution of the Republic of Latvia. Latvijas Vēstnesis. 1993, 43.

36 Levits. Eiropas Savienības Tiesības un Satversme, in Jundzis, T. (ed). Eiropas Tiesības. Otrais Papildinātais Izdevums. 2007, 579: 585-590; Ostrovska, supra note 12, p. 76; Par Rīgas teritorijas plānojuma daļas 2006-2018 gadam, kas attiecas uz Rīgas brīvostas teritoriju, atbilstību Latvijas Republikas Satversmes 115 pantam: Judgement of 17 January 2008 of the Constitutional Court in the Case No. 2007-11-03, para. 25.4. Latvijas Vēstnesis. 2008, No. 12.

37 Opinion of 17 September 2012 of the Commission on Constitutional Law. Par Latvijas Valsts Konstitucionālajiem Pamatiem un Neaizskaramo Satversmes Kodolu. p. 55-87 [interactive]. [accessed on 26-12-2012]. <http://www.president.lv/images/modules/items/PDF/17092012_Viedoklis_2.pdf >. 
of primacy applies to them, as well. ${ }^{38}$ The judge of the ECJ, Professor, Dr. h. c. Assessor. iur. and political analyst Egils Levits suggests that the situation with the rest of the Constitutional provisions is not so clear, but at the same time he indicates that the different views of the EU law and the constitutional law of Latvia on the primacy of EU law over Latvian national law have no practical importance, for no real conflicts between the EU law and the Constitution of Latvia are possible. ${ }^{39}$

This refers even more to the period following the entrance into force of the Treaty of Lisbon and the Charter of Fundamental Rights of the European Union ${ }^{40}$ (hereinafter the Charter) included in it, for no one can now question the standards of respect for human rights in the EU. When analysing the interaction between the EU law and the Convention for the Protection of Human Rights and Fundamental Freedoms (hereinafter the Convention), Jean-Paul Costa ${ }^{41}$, President of the European Court of Human Rights (hereinafter the ECHR), has indicated that the Charter says directly that the meaning and the scope of the rights provided by the Charter and corresponding to those in the Convention should be interpreted according to the provisions of this Convention, interpretation of which should comply with the case law of the ECHR referred to in Preamble of the Charter; Article 52, paragraph 3 of the Charter ${ }^{42}$ contains direct reference to the substantive provisions of the Convention that determine the minimum level of protection required under the Charter, thus the Convention indirectly becomes a part of the EU law and not just one of the elements of the general principles of law. ${ }^{43}$

On the basis of the conclusions drawn by Jean-Paul Costa, LL.M. cum laude Daina Celma suggests that the said provision of the Charter stipulates that EU courts cannot refer to the practice of the Convention and of the ECHR only as means of interpretation and arrive at a different result; this provision makes the position of the ECHR legally binding or recognizes it as the minimum level of protection of fundamental rights, thus, following the entrance into force of the Treaty of Lisbon, and even before EU had become the party to the Convention, the provisions of the Convention and also the interpretation provided by the ECHR indeed become formally binding on the EU courts. ${ }^{44}$ Consequently, the provisions of the Convention and the interpretation provided

38 Ostrovska, supra note 12, p. 76.

39 Levits, supra note 36, p. 589-592.

40 Charter of Fundamental Rights of the European Union, OJ 2010 C 83.

41 Annual Lecture by Mr Jean-Paul Costa, President of the European Court of Human Rights. [interactive]. [accessed on 27-12-2012]. <http://www.kcl.ac.uk/depsta/law/news/news_details.php?id=138>.

42 Article 52, paragraph 3 of the Charter: 'In so far as this Charter contains rights which correspond to rights guaranteed by the Convention for the Protection of Human Rights and Fundamental Freedoms, the meaning and scope of those rights shall be the same as those laid down by the said Convention. This provision shall not prevent Union law providing more extensive protection.'

43 Costa, J.P. The Relationship between the European Convention on Human Rights and European Union Law - A Jurisprudential Dialogue between the European Court of Human Rights and the European Court of Justice. Lecture at the King's College, London, 7 October 2008, p. 4 [interactive]. [accessed on 27-12-2012]. <http:/www.echr.coe.int/NR/rdonlyres/DA4C4A2E-0CBE-482A-A2059EA0AA6E31F6/0/2008_Londres_King_s_College_7_10.pdf >.

44 Celma. Eiropas Tiesu Mijiedarbība. Eiropas Cilvēktiesību Tiesa un Eiropas Savienības Tiesa: No Divām Nesaistītām Institūcijām Līdz Vienotai Sistēmai. Jurista Vārds. 2011, 52 (699). 
by the ECHR are without a doubt binding on Latvia and other member states that have become the party to the Convention.

A number of EU member states like Germany, France, Italy, Poland, Czech Republic and Lithuania have expressed their doubts about the primacy of EU law over national constitutions, mainly fundamental rights and fundamental principles included in them (i.e. basic constitutional values, or core or basis of national sovereignty). Only a few states like the Netherlands, Austria, Bulgaria and Estonia recognize the absolute primacy. ${ }^{45}$ However, it should be indicated that this regards to the period prior to the entrance into force of the Treaty of Lisbon.

The primacy of EU law over national law, except the core of the Constitution of Latvia, has also been accepted in the case law of Latvian courts. The Constitutional Court has pointed to the obligation of the corresponding interpretation in Paragraph 25.4 of its judgement of 17 January 2008 in the Case No.2007-11-03. The Department of Administrative Cases of the Senate, the Supreme Court of the Republic of Latvia (hereinafter the DAC of the Senate) in turn has resolved the conflict between EU law and Latvian law in favour of the EU law. ${ }^{46}$

Since the EU law consists not only of regulatory acts, but also the case law of the ECJ, the primacy of EU law refers to the latter, too. Freija, Lutere-Timmele and Vasariņš has stated that 'the binding force of a preliminary ruling with regard not only to the referring court but also to other courts is, first of all, based on the consideration that the ECJ does not announce a new provision with its preliminary ruling, but rather its interpretation is declaratory and becomes part of an interpretable act, provision or principle of Community law.' ${ }^{47}$ Legal provisions found by the ECJ through further lawmaking are just as binding as the written EU law, for like all systems of law the EU legal order cannot consist entirely of written provisions: there will always be gaps which have to be filled by unwritten law, and many of these gaps can be found in the EU regulatory acts. $^{48}$ The ECJ finds the justification for judge-made law in Article 220 of the Treaty establishing the European Community ${ }^{49}$, which stipulates that in the interpretation and application of this Treaty the law is observed. This means that the ECJ has been given the right not only to the interpretation of the Treaty, but also to the development of law in order to provide the EU with firm judicial basis. ${ }^{50}$

Consequently, national provisions, including those of Latvia, to which the principle of primacy of EU law refers, as well as the respective case law of national courts must

45 Borkoveca, supra note 9, p. 106-148.

46 Judgement of 5 March 2009 given by the DAC of the Senate in the Case No. A42347606, SKA-175/2009, para. 13 [interactive]. [accessed on 14-08-2012]. <www.at.gov.1v/files/docs/dupate_majas\%20lapai_senaats_2009.doc>.

47 Freija; Lutere-Timmele and Vasarinšs, supra note 16, p. 138.

48 Borharts, supra note 9, p. 82; Everling. On the Judge-Made Law of the European Community's Courts, in O'Keeffe, D. \& Bavasso, A. (eds.). Judicial Review in European Union Law. 2000, 29: 33, 35, 37.

49 This has currently been stipulated by Article 19, paragraph 1 of the Treaty on European Union.

50 Everling, supra note 48, p. 35; Joined Cases C-46/93 and C-48/93, Brasserie du Pêcheur SA v. Bundesrepublik Deutschland and The Queen v. Secretary of State for Transport, ex parte: Factortame Ltd and others. [1996] ECR I-01029, para. 27. 
not conflict with the case law of the ECJ, except the cases when the ECJ is systematically and significantly violating its competences. ${ }^{51}$

The principle of primacy of EU law ensures the unity and consistency in the application of the EU law. The ECJ judgement of 15 July 1964 in the Case 6/64, Costav. E.N.E.L., says that 'the executive force of Community law cannot vary from one state to another in deference to subsequent domestic laws without jeopardizing the attainment of the objectives of the Treaty set out in Article $5(2)^{52}$ and giving rise to the discrimination prohibited by Article 7'.

\subsection{Competence of the ECJ}

In accordance with Article 267 of the Treaty on the Functioning of the European Union (hereinafter the TFEU) and Article 19, paragraph 3 (b) of the Treaty on European Union (hereinafter the TEU), the ECJ gives preliminary rulings at the request of courts or tribunals of the member states on the interpretation of the Treaties ${ }^{53}$ and the validity and interpretation of acts of institutions, bodies, offices or agencies of the EU. Pursuant to Article 256, paragraphs 2 and 3 of the TFEU, the ECJ ensures the unity and consistency of EU law, but according to Article 19, paragraph 1 of the TEU, the law is observed in the interpretation and application of the Treaties. Articles 263, 264 and 267 of the TFEU and Article 19, paragraph 3 (b) of the TEU stipulate that the ECJ also performs functions of a constitutional court, i.e. gives preliminary rulings on the validity of acts of institutions, bodies, offices or agencies of the EU. As it has been already stated, the ECJ, considering its functions and competences, is actively engaged in further law-making.

Thus, paraphrasing the idea in legal science that constitution is what the high court decides it is ${ }^{54}$, it can be suggested that the EU law is what the ECJ decides it is by defining content of written EU law through interpretation by finding new provisions through further law-making and by rendering acts of institutions, bodies, offices or agencies of the EU invalid. Also, it should be noted that the general principles of the EU law, i.e. the principle of direct effect of EU law, the principle of primacy of EU law and the principle of state liability for breaches of EU law, have not been written in any regulatory acts, and they can only be found in the case law of the ECJ. ${ }^{55}$

The unity and consistency of the EU law can only be ensured on condition that the case law of the ECJ, i.e. the interpretation of provisions and provisions found through further law-making, as a binding legal source is applied to not only specific case, in which the question is raised, but also to each and every case in all member states, to which this case law applies. The binding force of a preliminary ruling 'can be explained

51 Everling, supra note 48, p. 42.

52 Article 5, paragraph 2 of the TEEC signed in 1957: member states shall abstain from any measures likely to jeopardise the attainment of the objectives of this Treaty.

53 Article 1 of both the TFEU and the TEU stipulates that 'Treaties' means the TFEU un the TEU.

54 Constantinesco, supra note 3, p. 75.

55 Ostrovska. Ārējo Normatīvo Tiesību Aktu Hierarhija Pēc Latvijas Pievienošanās Eiropas Savienībai (I). Likums un Tiesības. 2006, 2 (8, 46,78): p. 52. 
by the aim of the procedure referred to in Article 234 of the TEC, namely to ensure uniform interpretation of Community law in all the Community, and this aim might be jeopardized if the interpretation made by the ECJ is binding only on the case in which it has been offered'. ${ }^{56}$

Binding legal source is the case law included in both preliminary rulings and other judgements, for there is no sense in referring to the ECJ every question of interpretation of the EU law, when the question raised has already been answered in a ruling given in other procedure. As an institution ensuring the unity and consistency of the EU law, the ECJ will not make different interpretation of law just because this law has been applied in a ruling given in other procedure. This has been stated by the ECJ in paragraphs 13 and 14 of its judgement of 6 October 1982 in the Case 283/81, CILFIT. ${ }^{57}$ It is proved by the fact that the ECJ develops its case law relating to some legal question in judgements made in different procedures, e.g., in its judgement of 9 December 2003 in the Case C-129/00, Commission of the European Communities (hereinafter the CEC) v. Italian Republic ${ }^{58}$, which was given after considering the CEC's application for a declaration that the member state in question has failed to fulfil its obligations, the ECJ has referred to the legally important statement (case law) included in the preliminary ruling of 9 February 1999 in the Case C-343/96, Dilexport ${ }^{59}$, and has settled the case by declaring the failure to fulfil obligations on the basis of this case law. The said case law is as follows: if there is a presumption that the duties and charges unlawfully levied or collected when not due (the duties and charges collected on the basis of national provisions that are contrary to EU legal acts) have been passed on to third parties and the plaintiff is required to rebut that presumption in order to secure repayment of the charge, the provision in question must be regarded as contrary to Community law (paragraph 52 of judgement given in the Case C-343/96, paragraph 26 of judgement given in the Case C-129/00). This is how the ECJ has concretized the principle of effectiveness derived from the principle of sincere cooperation referred to in Article 4, paragraph 3 of the TEU (formerly Article 10 of the TEC): the detailed procedural rules laid down by each member state and governing actions for safeguarding rights which individuals derive from EU law must not render virtually impossible or excessively difficult the exercise of rights conferred by EU law. ${ }^{60}$

As it has been already stated, the procedure of preliminary ruling is regulated not only by the EU regulatory acts, but also by the specific case law of the ECJ. The judgement of 6 October 1982 in the Case 283/81, CILFIT, can be considered very significant, for it specifies restrictions on the obligation imposed on a court of a member

56 Freija; Lutere-Timmele and Vasarinšs, supra note 16, p. 138.

57 See: Case 283/81, Srl CILFIT and Lanificio di Gavardo SpA v. Ministry of Health, [1982] ECR 03415. All the case law of the ECJ, and not just preliminary rulings, has been recognized binding by the French Cour de Cassation in its practice. Nourissat, supra note 10, p. 252.

58 Case C-129/00, Commission of the European Communities v. Italian Republic, [2003] ECR I-14637, para. 7, 26, 27, 31 and 40 .

59 Case C-343/96, Dilexport Srl v. Amministrazione delle Finanze dello Stato, [1999] ECR I-00579, para. $52-54$.

60 See, for instance, Case C-129/00, Commission of the European Communities v. Italian Republic, para. 25. 
state, against which decisions there is no judicial remedy under national law to refer to the ECJ the question for a preliminary ruling. ${ }^{61}$ The following are the cases, when such a court of a member state can decide not to refer to the ECJ the question for a preliminary ruling, as defined by the ECJ:

1) The question is not relevant, i.e., the answer to that question, regardless of what it may be, can in no way affect the outcome of the case;

2) The ECJ has already dealt with the point of EU law in question, irrespective of the nature of the proceedings which led to those decisions; this especially regards the situations, when the question raised is materially identical with a question, which has already been the subject of a preliminary ruling in a similar case, and even the situations, when the questions at issue are not strictly identical;

3 ) The correct application of EU law is so obvious that it does not leave no scope for any reasonable doubt; before it comes to the conclusion that such is the case, the national court or tribunal of a member state must be convinced that the matter is equally obvious to the courts of the other member states and to the ECJ. ${ }^{62}$

In the above-mentioned case, the ECJ in its preliminary ruling has not made the interpretation of the provision (which was then included in Article 177 of the TEEC and has still remained the same in substance, except that now it can be found in Article 267 of the TFEU), but rather has undertaken further law-making activity - teleological reduction. The ECJ has imposed the restriction on the provision defined too broadly and further made the provision through teleological reduction as follows: if a question concerning the interpretation of the Treaties or acts of institutions, bodies, offices or

61 One restriction was already specified before: judgement of 27 March 1963 given by the ECJ in the Joined Cases 28/62, 29/62 and 30/62, Da Costa, says the following: although the third paragraph of Article 177 of the TEEC unreservedly requires courts or tribunals of a member state against whose decisions there is no judicial remedy under national law to refer to the court every question of interpretation raised before them, the authority of an interpretation under article 177 already given by the court may deprive the obligation of its purpose and thus empty it of its substance; such is the case especially when the question raised is materially identical with a question which has already been the subject of a preliminary ruling in a similar case and no new factor has been presented to the court. Joined Cases 28/62, 29/62 and 30/62, Da Costa en Schaake NV, Jacob Meijer NV, Hoechst-Holland NV v. Netherlands Inland Revenue Administration, [1963] ECR 00031.

62 See: Case 283/81, CILFIT, para. 10, 13, 14, 16 and 21.

A similar rule, which, however, relates to preliminary rulings only, has been included in Article 104, paragraph 3 of the Rules of Procedure of the ECJ of 19 June 1991 (still valid):

'Where a question referred to the Court for a preliminary ruling is identical to a question on which the Court has already ruled, or where the answer to such a question may be clearly deduced from existing case-law, the Court may, after hearing the Advocate General, at any time give its decision by reasoned order in which reference is made to its previous judgment or to the relevant case-law.

The Court may also give its decision by reasoned order, after informing the court or tribunal which referred the question to it, hearing any observations submitted by the persons referred to in Article 23 of the Statute and after hearing the Advocate General, where the answer to the question referred to the Court for a preliminary ruling admits of no reasonable doubt.'

Rules of Procedure of the Court of Justice (consolidated), OJ 2010 C 177.

Rules of Procedure of the Court of Justice of 4 December 1974, which was later replaced with the Rules of Procedure of the Court of Justice of 19 June 1991, did not contain such provisions. Rules of Procedure of the Court of Justice, OJ 1974, Vol.17, L 350. 
agencies of the EU has been raised before a court of a member state, against which decisions there is no judicial remedy under national law, except the cases when the question is not relevant or the ECJ has already interpreted the specific point of the EU law or when the correct application of the EU law is so obvious that it does not leave no scope for any reasonable doubt, this court of the member state then should refer this question to the ECJ. Teleological reduction has been used on the basis of Article 177, paragraph 3 of the TEEC, which is to prevent the occurrence within the EU territory of divergences in judicial decisions on questions of the EU law (see paragraph 7 of the judgement).

Following the entrance into force of the ECJ judgement of 6 October 1982 in the Case 283/81, CILFIT, courts of EU member states refer questions to the ECJ exactly on the basis of this provision reduced by the ECJ, e.g., the DAC of the Senate in paragraph 16 of its judgement given on 5 March 2009 in the Case No.A42347606, SKA-175/2009, has based its rights not to raise the question in the specific case exactly on this judge-made law, for the EU founding Treaties have never stipulated any exceptions to the obligation of courts of a member state to raise such question. Thus, this provision reduced by the ECJ in its judgement of 6 October 1982 in the Case 283/81, CILFIT, acknowledges that binding force to the case law of the ECJ is assigned by its competence (rights and duties), which is defined in Article 256, paragraphs 2 and 3, Articles 263, 264, 267 of the TFEU and Article 19, paragraph 1, paragraph 3 (b) of the TEU and from which the ECJ has derived its rights to use further law-making.

\subsection{The Principle of State Liability}

According to the principle of state liability established by the ECJ, a member state must be liable for breaches of EU law. Member state's liability for breaches may be established by any branch of the government, i.e. the legislature, executive or judiciary, which has caused this breach. ${ }^{63}$ The principle of state liability, namely the obligation to make reparation for the loss and damage, for breach of EU law was first referred to by the ECJ in its judgement of 19 November 1991 given in the Joined Cases C-6/90 un C-9/90, Andrea Francovich and Danila Bonifaci and others v. Italian Republic ${ }^{64}$, and later were developed and improved in many other judgements. The ECJ itself suggests that this principle has been drawn from provisions currently included in Article 4, paragraph 3 of the TEU and Article 340 of the TFEU, as well as it has been derived from the general principle common and familiar to the legal systems of member states that an unlawful act or omission gives rise to an obligation to make the damage caused good. ${ }^{65}$

State liability for ignoring the case law of the ECJ should be analysed in connection with the status of the case law of the ECJ. It is clear from the case law of the ECJ that

63 Case C-129/00, Commission of the European Communities v. Italian Republic, para. 29.

64 Joined Cases C-6/90 and C-9/90, Andrea Francovich and Danila Bonifaci and others v. Italian Republic, [1991] ECR I-05357, para. 36. See: Craig and Búrca, supra note 5, p. 241.

65 See: Joined Cases C-6/90 and C-9/90, Francovich, para 36; Joined Cases C-46/93 and C-48/93, Brasserie, para. 27-29. See also: Craig, P. and de Búrca, G. EU Law. Text, Cases, and Materials. $4^{\text {th }}$ edition. 2008, p. 332 . 
three conditions must be satisfied for a member state to be required to make reparation for loss and damage caused as a result of breaches of EU law: 1) the rule of law infringed must have been intended to confer rights on individuals; 2) the breach must be sufficiently serious; and 3) there must be a direct causal link between the breach of the obligation resting on the State and the loss or damage sustained by the injured parties. State liability for loss or damage caused by a decision of a national court adjudicating at last instance which infringes a rule of EU law is governed by the same conditions. ${ }^{66}$

As the ECJ has declared in paragraph 57 of its judgement of 5 March 1996 given in the Joined Cases C-46/93 and C-48/93, Brasserie, a breach of EU law is sufficiently serious if it has persisted despite a judgement finding the infringement in question to be established, or a preliminary ruling or settled case law of the ECJ on the matter, from which it is clear that the conduct in question constituted an infringement. A similar statement has been included in paragraph 56 of the ECJ judgement of 30 September 2003 in the Case C-224/01, Köbler: in any event, an infringement of EU law is sufficiently serious, where the decision concerned was made in manifest breach of the case law of the ECJ in the matter. Paragraph 43 of the ECJ judgement of 13 June 2006 in the Case C-173/03, Traghett $^{67}$, also says that a manifest infringement of EU law is in any event presumed, where the decision involved is made in manifest disregard of the case law of the ECJ on the subject. Thus, if a court or tribunal of a member state against which decisions there is no judicial remedy under national law ignores the case law of the ECJ, namely, adopts a decision, which is not compatible with this case law, legal consequences - the state liability for a breach of EU law - are established. Thus, the author concludes that the case law of the ECJ has binding force because legal consequences may be established only for breaches of binding legal norm.

There is no doubt that the case law of the ECJ is binding not only on courts of member states, but also on the legislature and the executive, e.g., if the ECJ in its judgement of 9 February 1999 given in the Case C-167/97, Regina v. Secretary of State for Employment, through interpretation of Article $119^{68}$ of the TEC, has declared that the compensation for an unfair dismissal falls within the definition of pay ${ }^{69}$, Latvia may not adopt the regulatory framework conflicting with this interpretation within the areas of EU competence. ${ }^{70}$

66 See, for instance, Case C-224/01, Gerhard Köbler v. Republik Österreich, [2003] ECR I-10239, para. 51, 52; Case C-424/97, Salomone Haim v. Kassenzahnärztliche Vereinigung Nordrhein, [2000] ECR I-05123, para. 36.

67 Case C-173/03, Traghetti del Mediterraneo SpA v. Repubblica Italiana, [2006] ECR I-05177.

68 Article 141 of the TEC stipulates that 'pay' means the ordinary basic or minimum wage or salary and any other consideration, whether in cash or in kind, which the worker receives directly or indirectly, in respect of his employment, from his employer. Treaty establishing the European Community (consolidated), OJ 1992, Vol.35, C 224.

69 Case C-167/97, Regina v. Secretary of State for Employment, ex parte Nicole Seymour-Smith and Laura Perez, [1999] ECR I-00623, para. 28.

70 See: Article 2, paragraphs 1 and 2 of the TFEU. 


\subsection{Conclusions from Chapters A-D}

It follows from the chapters above that the legally important statements that the ECJ has found through further law-making or judge-made law comply with all three characteristics of a provision (legal norm), namely:

1) They have binding force (a provision regulating the behaviour of a legal subject determines how something must be rather than how something is);

2) Their applicability is enforced by national executive and judicial bodies;

3) They are applicable repeatedly and relate to an indefinite number of persons. ${ }^{71}$

The case law of the ECJ applies not only to the parties in the specific case, but also to an indefinite number of persons, therefore, it can be applied repeatedly. An excellent example is the provision that was found through teleological reduction by the ECJ in its judgement of 6 October 1982 in the Case 283/81, CILFIT, and referred to previously. This must be taken into consideration by all courts of member states, against which decisions there is no judicial remedy under national law, not just by the court that has raised the specific question.

Applicability of the case law of the ECJ is enforced according to the principle of state liability, the obligation on a member state referred to in Article 260 of the TFEU to take the necessary measures to comply with the judgement of the ECJ if the ECJ has found that a member state has failed to fulfil an obligation under the Treaties, as well as the right of the ECJ referred to in the same Article to impose a lump sum or penalty payment on this member state. The member state's failure to fulfil an obligation under the Treaties is sometimes found by the ECJ on the basis of its own case law. ${ }^{72}$ This means that the judge-made law of the ECJ is just as binding as the provisions included in the EU law.

Interpretation of written legal provision (also its result) made by the ECJ is not a newfound legal provision, yet it is binding as such that reveals content of the specific provision and, consequently, as a provision itself, for the EU legal provision and its interpretation made by the ECJ form an inseparable unit. It has been said in legal science that interpretation helps to reveal the content, meaning, aim, grounds, purpose of the text of provision - all 'that is known as ratio legis in science of the law' ${ }^{73}$ According to Vlad Constantinesco, judge interprets and defines the will of the legislator and without

71 Iljjanova, supra note 27, p. 34-35; Rezevska. Judikatūra kā Tiesību Avots: Izpratne un Pielietošana. Latvijas Republikas Augstākās Tiesas Biļetens, 1, p. 31; Kalniņš. Tiesību Normu Piemērošanas Loǵiskā Shēma, in Meļkisisis, E. (scient. ed.). Juridiskās Metodes Pamati. 11 Soļi Tiesību Normu Piemērošanā. 2003, 18: 19; Jelāgins. Tiesību Pamatavoti, in Mel̦kisis, E. (ed.). Mūsdienu Tiesību Teorijas Atzinas: Mācību Grāmata / Rakstu Krājums. 1999, 59: 66.

72 E.g., in judgement of 9 December 2003 given in the Case C-129/00, Commission of the European Communities v. Italian Republic, the ECJ referred to the legally important statement (case law) included in the preliminary ruling of 9 February 1999 in the Case C-343/96, Dilexport, and decided the case, namely found the failure to fulfil obligations, exactly on the basis of this statement.

73 Meļ̧isisis. Tiesību Normu Iztulkošana, in Mel̦kisis, E. (scient. ed.). Juridiskās Metodes Pamati. 11 Soļi Tiesību Normu Piemērošanā. 2003, 110: 110-111. 
the judge it lacks reality and affect and only action of the judge makes it alive. ${ }^{74}$ The meaning of the applicable EU law in turn is found by a court or a judge of a member state through raising questions, and the ECJ judgement is a 'legally valid final answer' about the content of EU law. ${ }^{75} \mathrm{As}$ it has been already stated, persons applying the law in member states discover the meaning of EU law by becoming acquainted with the case law of the ECJ found in both preliminary rulings and other judgements.

\subsection{The Binding Force of the ECJ in Practice - in Judgements of Various Courts}

The ECJ has stated that the operative part of its judgement must be understood in the light of the grounds of the judgement. ${ }^{76}$ Consequently, the case law contained both in the operative part and the grounds of any ECJ judgement is binding. This can be noted in the ECJ judgement of 16 March 1978 in the Case 135/77, Robert Bosch, in which the operative part consists of the operative part and the grounds of a preliminary ruling given previously. ${ }^{77}$

The ECJ has recognized its case law and has used it as a binding legal source in many of its judgements, as can be seen from several examples described above. In addition, it should be noted that the ECJ sometimes refers to its previous judgements as to the provisions in the operative part of the judgement. ${ }^{78}$ The European Commission (former CEC) also recognizes the case law of the ECJ as binding, e.g., in its application for a declaration that the member state has failed to fulfil its obligations, the European Commission indicated that Italy has breached what has been stated in the ECJ judgements ${ }^{79}$, and in the judgement of 27 March 1963 in the Joined Cases 28/62, 29/62 un 30/62, Da Costa, the European Commission asked to decline the question raised, for it was identical with the question of interpretation already decided by the ECJ.

The case law of the ECJ is also applied by Latvian courts that consider it to be a binding legal source. As it has been already stated, the DAC of the Senate in paragraph 16 of its judgement given on 5 March 2009 in the Case No.A42347606, SKA-175/2009, has based its rights not to raise the question in the specific case on the provision found through teleological reduction by the ECJ in its judgement of 6 October in the Case 283/81, CILFIT. In turn, the Department of Civil Cases of the Senate, the Supreme Court of the Republic of Latvia (hereinafter the DCC of the Senate), in its judgement of 14 October 2009 in the Case No.SKC-899 decided the case (judgement of 20 April 2009 given by the Civil Division of Riga Regional Court was in part set aside) on the basis of

74 Constantinesco, supra note 3, p. 73-74.

75 Kollatz, U. and Priednieks, K. Eiropas Tiesības: Lietu un Materiālu Izlase. 2000, p. 17.

76 Case 135/77, Robert Bosch GmbH v. Hauptzollamt Hildesheim, [1978] ECR 00855, para. 4.

77 Ibid., para. 4, operative part, Case 1/77, Robert Bosch, para. 5, operative part. Case 1/77, Robert Bosch GmbH v. Hauptzollamt Hildesheim, [1977] ECR 01473.

78 See, for instance, Joined Cases 28/62, 29/62 and 30/62, Da Costa; Case C-173/03, Traghetti.

79 See: Case C-129/00, Commission of the European Communities v. Italian Republic, para. 10, 15. 
the interpretation of provision made in Article 28 of the ECJ judgement of 9 February 1999 in the Case C-167/97, Regina v. Secretary of State for Employment. ${ }^{80}$

There are certainly unflattering examples as well, showing that more than seven years after Latvia's accession to the EU some Latvian courts still lack even elementary knowledge of EU law. Such is the decision of 9 June 2011 made by the Administrative Regional Court in the Case No.AA43-2511-11/14. ${ }^{81}$ In this Case the Administrative Regional Court had to decide whether it was possible to examine in administrative proceedings an application for seeking damages from the state caused by the DCC of the Senate that precisely had delivered the opposite judgement to the case law of the ECJ, namely to the interpretation of the provision made in paragraph 28 of the ECJ judgement of 9 February 1999 in the Case C-167/97, Regina v. Secretary of State for Employment. The Administrative Regional Court has referred to the Administrative Procedure Law and Law 'On Judicial Power' ${ }^{2}$, but nowhere has it mentioned any of the EU legal acts stating categorically in paragraph 7 of its decision in the Case No.AA43-2511-11/14 that: 'Objections raised by the applicant against the lawfulness of the final judgement do not deserve judicial protection. ${ }^{93}$

\subsection{Why the Case Law of the ECJ is an Independent Additional Legal Source in Latvia}

As it has been already clarified above, the judge-made law of the ECJ is just as binding as the provisions included in the EU regulatory acts. In turn, the interpretation of written legal provision made by the ECJ is binding, for the EU legal provision and its interpretation made by the ECJ form an inseparable unit, therefore, the case law of the ECJ is a binding legal source. According to the criterion of binding force, legal sources in Latvia have been divided into the group of independent legal sources, which are universally binding and contain legal provisions, and into the group of subsidiary legal sources, which are not binding. The independent legal sources in turn consist of basic legal sources and additional legal sources. ${ }^{84}$ Latvia, like other states of the continental Europe or Romano-Germanic law family ${ }^{85}$, belongs to the so called written law countries,

80 Judgement of 14 October 2009 given by the DCC of the Senate in the Case No.SKC-899, para. 10.2, 10.2.1, 10.2.2, 10.2.4, 10.2.5 [interactive]. [accessed on 29-08-2012]. $<$ http://www.at.gov.lv/files/archive/ department1/2009/899-09.doc $>$. If courts are bound by the judgement given by some institution and they are not entitled to derogate from it (namely, a higher court will set aside the judgement of a lower court if this judgement conflicts with the judgement of the higher court), this judgement is considered to be binding. Iljanova, supra note 27, p. 66.

81 Judgement of 9 June 2011 of the Administrative Regional Court in the Case No. AA43-2511-11/14, unpublished.

82 Par Tiesu Varu: The Law of the Republic of Latvia. Latvijas Republikas Augstākās Padomes un Valdības Ziņotājs 1993, 1.

83 For more detailed information about this case, see: Slaṇke. Eiropas Savienības Tiesības Latvijā Maldugunis Purvā?. [interactive]. ]accessed on 29-08-2012]. <http://www.ir.lv/2011/11/22/es-tiesibaslatvija-maldugunis-purva>.

84 Iljanova, supra note 27, p. 57-58.

85 Osipova, S. Viduslaiku Tiesību Spogulis. 2004, p. 10, 12. 
where only regulatory acts are recognized as independent basic legal sources. Therefore, the case law of the ECJ can be added to the independent additional legal sources, i.e. the unwritten legal sources which consist of binding provisions and the source of which is the sovereign, not the legislator, namely general principles of law and customary law. ${ }^{86}$ The described system of legal sources can be represented in a diagram as follows:

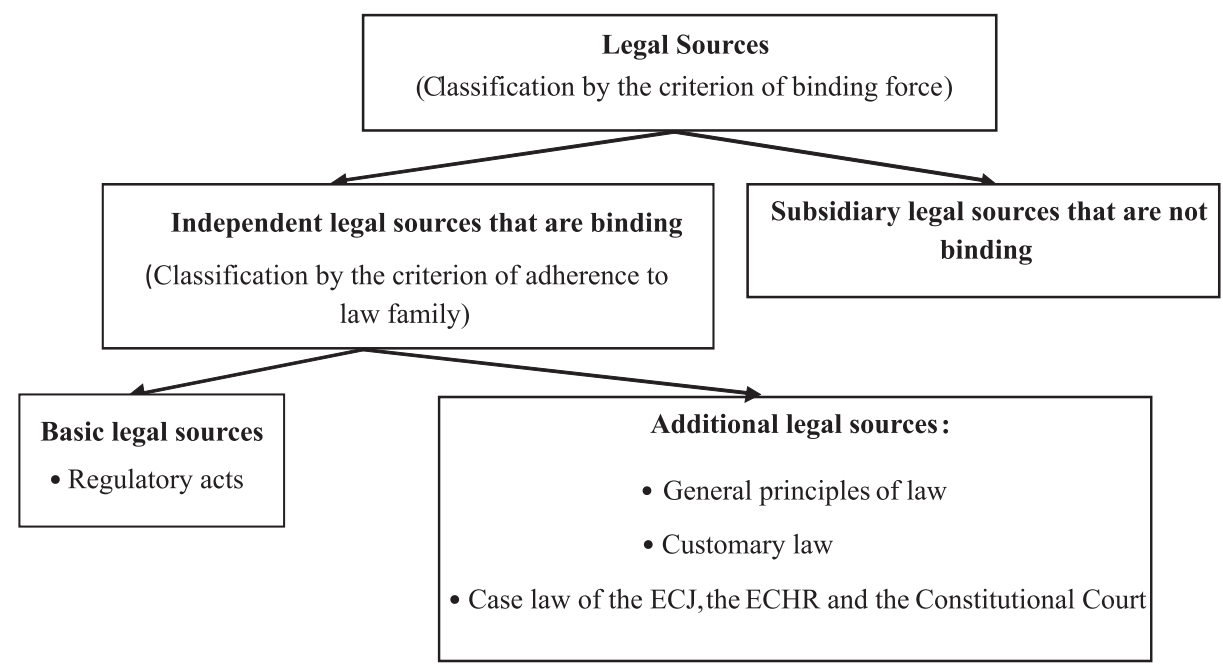

Although it has been stated in Latvian regulatory acts that the case law of the ECJ must be taken into consideration ${ }^{87}$, its binding force has not been specifically regulated. Since the majority of the persons applying the law does not have a broad knowledge of EU law, it would be advisable to directly write in all procedural laws that the case law of the ECJ is binding an independent additional legal source in Latvia and that the provisions found by the ECJ through further law-making should be respected just as those included in the regulatory acts, but the interpretation made by the ECJ bindingly determines the content of the EU written provisions, therefore, they should be applied in this interpretation only. While this has not happened yet, it is important to advance the understanding of the case law of the ECJ as a binding legal source by inscribing it in legal doctrine.

Taking into account that in areas, such as the labour law, which are regulated by EU law, a significant part of the law can be found in the interpretation of provisions made by the $\mathrm{ECJ}^{88}$ and also in the provisions found through further law-making, all the case law

86 Rezevska. Judikatūra kā Tiesību Avots: Izpratne un Pielietošana. Latvijas Republikas Augstākās Tiesas Biletens. 1: 29, 31 .

87 The fact that the case law of the ECJ must be taken into consideration has been stipulated in three procedural laws of Latvia, namely in paragraph 4, Section 15 of the Administrative Procedure Law, in paragraph 6, Section 5 of the Civil Procedure Law and in paragraph 2, Section 2 of the Criminal Procedure Law. Administratīvā Procesa Likums: The Law of the Republic of Latvia. Latvijas Vēstnesis. 2001, 164; Civilprocesa Likums: The Law of the Republic of Latvia, Latvijas Véstnesis. 1998, 326/330; Kriminālprocesa Likums: The Law of the Republic of Latvia. Latvijas Vēstnesis. 2005, 74. 
of the ECJ translated into Latvian should be available publically, pursuant to Article 90 of the Constitution of Latvia, which stipulates that everyone has the right to know his/ her rights.

\section{Binding Case Law rather than the Judge-Made Law (Binding Precedents)}

The ECJ judgements are often referred to as the precedents, and this is the most common view in legal science. ${ }^{89}$ Legal doctrine also suggests that authors rarely explain what meaning they assign to the term 'precedent', and it is obvious that they often mean a former ECJ judgement, which has persuasive rather than binding force. ${ }^{90}$ Sometimes the ECJ judgements are simply called precedents which, in contradistinction to the English law, are not binding. ${ }^{91}$

The author considers that the ECJ judgements are not binding precedents (judgemade law) on courts of member states, for it is legally important statements of the ECJ that are binding on them. In common law countries, the process of legal thinking, when the persons applying the law consult legal sources in order to deal with a specific case, is inductive: the basic source is the judgement in the specific case, namely a precedent used to deal with a similar actual case. ${ }^{92}$ Court is formally bound by its judgements, which means that they must be respected (the so called principle of stare decisis), and the judgement, which differs from former judgements, can only be made provided the actual circumstances of the specific case are different from the situations resolved with former judgements. ${ }^{93}$ In turn, in Romano-Germanic law countries, the process of legal thinking of persons applying the law is deductive: the basic source is an abstract provision consulted when dealing with a specific case..$^{94}$

The author agrees with the Associate Professor of the University of Latvia, Faculty of Law, Dr. iur. Jānis Nemainis that according to the leading opinion in common law countries, a precedent is related to the actual circumstances of the case, while judgemade law in Romano-Germanic law countries results from abstract general rules and aspires to become legal provision, therefore, it is not related to the actual circumstances of the case. ${ }^{95}$ Thus, the author disagrees with Ginta Sniedzite, who has suggested that the ECJ has established the system of stare decisis with regard to its judgements in the

89 Марченко, supra note 2, p. 461-462. See, for instance, Sniedzìte, supra note 17, p. 64-65, 67; Eberts, supra note 8, p. 24; Nourissat, supra note 10, p. 253.

90 Barceló. Precedent in European Community Law, in MacCormik, D.N. and Summers, R.S. (eds.). Interpreting Precedents: A Comparative Study. 1997, 407: 415.

91 Everling, supra note 48, p. 31, 39.

92 Iljanova, supra note 27, p. 50.

93 Levits, supra note 15, p. 32.

94 Iljanova, supra note 27, p. 50.

95 Neimanis, J. Tiesību Tālākveidošana. 2006, p. 20-21. 
judgement of 27 March 1963 in the Joined Cases 28/62, 29/62 and 30/62, Da Costa. ${ }^{96}$ In this judgement, the ECJ has made the teleological reduction of the provision included in Article 177 of the TEEC and imposed the restriction on the provision defined too broadly. The provision further made through teleological reduction is as follows: if a question concerning the interpretation of the Treaties or acts of institutions, bodies, offices or agencies of the EU has been raised before a court of a member state, against which decisions there is no judicial remedy under national law, except the cases when the ECJ has already interpreted the specific point of law in accordance with Article 177 of the TEEC, especially in situations, when the question raised is materially identical with a question which has already been the subject of a preliminary ruling in a similar case and no new factor has been presented to the court, this court of the member state then should refer this question to the ECJ. Teleological reduction has been used on the basis of Article 177, paragraph 3 of the TEEC, which is to prevent the occurrence within the EU territory of divergences in judicial decisions on questions of EU law (see paragraph 7 of the judgement). As it has been already indicated in this judgement, the teleological reduction has been used on the basis of Article 177 of the TEEC, which is to prevent the occurrence within the EU territory of divergences in judicial decisions on the questions of EU law.

In a preliminary ruling the ECJ interprets EU law, i.e. deals with legal problems, while a national court must apply this interpretation to the facts of the specific case this has been recognized by both the ECJ itself and legal scientists. ${ }^{97}$ A national court should also apply the provisions found by the ECJ through further law-making. If the ECJ renders some EU legal act invalid, this act can no longer be applied from the moment determined by this court. ${ }^{98}$ National courts do not examine cases regarding the interpretation or validity of EU legal acts, therefore, the ECJ judgements cannot be precedents on these courts. The same refers to the ECJ judgements made in different procedures like the judgements finding failure of a member state to fulfil its obligations, for such cases do not fall within the jurisdiction of national courts, as well.

There is also an opinion that the ECJ combines the characteristics and methods of the written law and the judge-made law in order to create something new.99

\section{Conclusions}

1. Following the entrance into force of the Declaration concerning primacy (hereinafter the Declaration) and annexed to the Final Act of the Intergovernmental Conference which adopted the Treaty of Lisbon on 1 December 2009, the binding force of the case law of the Court of Justice of the European Union (hereinafter the ECJ) has

\footnotetext{
96 Sniedzite, supra note 17, p. 64.

97 See: Joined Cases 28/62, 29/62 and 30/62, Da Costa; Freija; Lutere-Timmele and Vasarinšs, supra note 16, p. 137-138.

98 Freija; Lutere-Timmele and Vasarinšs, supra note 16, p. 140.

99 Constantinesco, supra note 3, p. 74, 75.
} 
been recognized by the main legislator of the European Union (hereinafter the EU), i.e. totality of the member states, at least as a statement of political will. Such status to the case law of the ECJ by the Declaration has been given (de facto - accepted) by recognizing the general principles of law and their concretization included in the case law of the ECJ as binding legal provisions, regardless of whether they are written in any of the EU regulatory acts, including the EU founding treaties.

2. EU law is what the ECJ decides it is by defining content of written EU law through interpretation, by finding new provisions through further law-making and by rendering acts of institutions, bodies, offices or agencies of the EU invalid. The unity and consistency of the EU law can only be ensured on condition that the case law of the ECJ as a binding legal source is applied to not only specific case, in which the question is raised, but also to each and every case in all member states to which this case law applies.

3. A binding legal source is the case law included in both preliminary rulings and other judgements, for there is no sense in referring to the ECJ every question of interpretation of EU law, when the question raised has already been answered in a ruling given in other procedure. As an institution ensuring the unity and consistency of the EU law, the ECJ will not make different interpretation of law just because this law has been applied in a ruling given in other procedure. This has been stated by the ECJ in paragraphs 13 and 14 of its judgement of 6 October 1982 in the Case 283/81, CILFIT. It is proved by the fact that the ECJ develops its case law relating to some legal question in judgements made in different procedures.

4. The legally important statements that the ECJ has found through further lawmaking or judge-made law comply with all three characteristics of a provision (legal norm), i.e. the judge-made law of the ECJ is just as binding as the provisions included in the EU law. The interpretation of written legal provision (also its result) made by the ECJ is not a newfound legal provision, yet it is binding as such that reveals content of the specific provision and, consequently, as a provision itself, for the EU legal provision and its interpretation made by the ECJ form an inseparable unit. Consequently, the case law of the ECJ is a binding legal source.

5. Latvia, like other states of the continental Europe or Romano-Germanic law family, belongs to the so called written law countries, where only regulatory acts are recognized as independent basic legal sources. Therefore, the case law of the ECJ can be added to the independent additional legal sources, i.e. the unwritten legal sources, which consist of binding provisions and the source of which is the sovereign, not the legislator, namely general principles of law and customary law.

6. The ECJ judgements are not binding precedents (judge-made law) on courts of member states, for it is legally important statements of the ECJ that are binding on them. In a preliminary ruling, the ECJ interprets EU law, i.e. deals with legal problems, while a national court must apply this interpretation to the facts of the specific case - this has been recognized by both the ECJ itself and legal scientists. A national court should also apply the provisions found by the ECJ through further law-making. If the ECJ renders some EU legal act invalid, this act can no longer be applied from the moment determined by 
this court. National courts do not examine cases regarding the interpretation or validity of EU legal acts, therefore, the ECJ judgements cannot be precedents on these courts. The same refers to the ECJ judgements made in different procedures like the judgements finding failure of a member state to fulfil its obligations, for such cases do not fall within the jurisdiction of national courts, as well.

\section{References}

Administratīyā Procesa Likums: The Law of the Republic of Latvia. Latvijas Véstnesis. 2001, No. 164.

Amos, M. Rule of Law or Judicial Activism Two Perspectives on the European Court of Justice. Master thesis. Faculty of Law, University of Lund, Sweden. EC law, Spring 2003 [interactive]. [accessed on 04-082012]. <http://lup.lub.lu.se/luur/download?f unc $=$ downloadFile $\&$ recordOId $=1554673 \& \mathrm{f}$ ileOId $=1563405>$.

Annual Lecture by Mr Jean-Paul Costa, President of the European Court of Human Rights. [interactive]. [accessed on 27-122012]. <http://www.kcl.ac.uk/depsta/law/ news/news_details.php?id=138>.

Barceló, J. J. Precedent in European Community Law. In: Interpreting Precedents: $A$ Comparative Study. MacCormik, D. N. and Summers, R. S. (eds.). Aldershot: Darthmouth Publishing Company Ltd, 1997.

Borharts, K. D. Eiropas Savienības Tiesību Ceļvedis. Luksemburga: Eiropas Savienības Publikāciju Birojs, 2011.

Borkoveca, M. Dalībvalstu Tiesību Normu un Eiropas Savienības Tiesību Normu Kolīziju Risināšanas Problēmjautājumi. Doctoral thesis. [interactive]. [accessed on 10-082012]. < < <tps://luis.lanet.lv/pls/pub/luj. fprnt $?=1 \& \mathrm{fn}=\mathrm{F} 1235036252 /$ Marina $\% 20$ Borkoveca\%202011.pdf>.

Borkoveca, M. Eiropas Savienības Tiesību Sistēmas Mijiedarbība ar Dalībvalstu Tiesību Sistēmām. Jurista Vārds. 2010, 13 (608).
Case 1/77 Robert Bosch GmbHv. Hauptzollamt Hildesheim [1977] ECR 01473.

Case 106/77 Amministrazione delle Finanze dello Stato v. Simmenthal SpA [1978] ECR 00629.

Case 11/70 Internationale Handelsgesellschaft $m b H$ pret Einfuhr- und Vorratsstelle für Getreide und Futtermittel [1970] ECR 01125.

Case 135/77 Robert Bosch GmbH v. Hauptzollamt Hildesheim [1978] ECR 00855.

Case 26/62 NV Algemene Transport- en Expeditie Onderneming van Gend \& Loos v. Netherlands Inland Revenue Administration [1963] ECR 00001.

Case 283/81 Srl CILFIT and Lanificio di Gavardo SpA v. Ministry of Health [1982] ECR 03415.

Case 294/83 Parti écologiste 'Les Verts'v. European Parliament [1986] ECR 01339.

Case 6/60 Jean-E. Humblet v. Belgian State [1960] ECR 00559.

Case 6/64 Flaminio Costa v. E.N.E.L. [1964] ECR 00585.

Case C-129/00 Commission of the European Communities v. Italian Republic [2003] ECRI-14637.

Case C-167/97 Regina v. Secretary of State for Employment, ex parte Nicole Seymour-Smith and Laura Perez [1999] ECR I-00623.

Case C-173/03 Traghetti del Mediterraneo SpA v. Repubblica Italiana [2006] ECR I-05177.

Case C-224/01 Gerhard Köbler v. Republik Österreich [2003] ECR I-10239. 
Case C-285/98 Tanja Kreil v. Bundesrepublik Deutschland [2000] ECR I-00069.

Case C-343/96 Dilexport Srl v. Amministrazione delle Finanze dello Stato [1999] ECR I-00579.

Case C-424/97 Salomone Haim v. Kassenzahnärztliche Vereinigung Nordrhein [2000] ECR I-05123.

Celma, D. Eiropas Tiesu Mijiedarbība. Eiropas Cilvēktiesību Tiesa un Eiropas Savienības Tiesa: No Divām Nesaistītām Institūcijām Līdz Vienotai Sistēmai. Jurista Vārds. 2011, 52 (699).

Charter of Fundamental Rights of the European Union. OJ, 30 March 2010, C 83.

Civilprocesa Likums: The Law of the Republic of Latvia. Latvijas Vēstnesis. 1998, No. 326/330.

Constantinesco, V. The ECJ as a Law Maker: Praeter aut Contra Legem? In: Judicial Review in European Union Law. O'Keeffe, D. \& Bavasso, A. (eds.). The Hague: Kluwer Law International, 2000.

Costa, J. P. The Relationship between the European Convention on Human Rights and European Union Law - A Jurisprudential Dialogue between the European Court of Human Rights and the European Court of Justice. Lecture at the King's College, London, 7 October 2008 [interactive]. [accessed on 27-12-2012]. <http://www.echr. coe.int/NR/rdonlyres/DA4C4A2E-0CBE482A-A205-9EA0AA6E31F6/0/2008 Londres_King_s_College_7_10.pdf $>$.

Craig, P. and de Búrca, G. EU Law. Text, Cases, and Materials. 5th edition. New York: Oxford University Press Inc., 2011.

Craig, P. and de Búrca, G. EU Law. Text, Cases, and Materials. 4th Edition. New York: Oxford University Press, Inc., 2008.

Declaration concerning primacy: Declarations, annexed to the Final Act of the Intergovernmental Conference which adopted the Treaty of Lisbon, signed on 13 December 2007. OJ, 17 December 2007, C 306/02.
Dupate, K. Eiropas Savienības Tiesas Prakse Darba Tiesībās. Rīga: Latvijas Brīvo Arodbiedrību Savienība, 2011.

Eberts, D. Eiropas Tiesības Latvijas Tiesu Praksē. Ievads Eiropas Tiesībās. In: Eiropas Savienības Tiesību Piemērošana. Rokasgrāmata Praktizējošiem Juristiem. Otrais Papildinātais Izdevums. LutereTimmele, D. L. (zin. red.). Rīga: Tiesu Namu Aǵentūra, 2008.

Kollatz, U. and Priednieks, K. Eiropas Tiesības: Lietu un Materiālu Izlase. Rīga: Latvijas Universitāte, 2000.

Everling, U. On the Judge-Made Law of the European Community's Courts. In: Judicial Review in European Union Law. O'Keeffe, D. \& Bavasso, A. (eds.). The Hague: Kluwer Law International, 2000.

Freija, I.; Lutere-Timmele, D. L. and Vasariņš, N. Prejudiciālais Nolēmums. In: Eiropas Savienības Tiesību Piemērošana. Rokasgrāmata Praktizējošiem Juristiem. Otrais Papildinātais Izdevums. LutereTimmele, D. L. (zin. red.). Rīga: Tiesu Namu Aǵentūra, 2008.

Harbaceviča, S. Eiropas Savienības Tiesību Ieviešana Latvijā. In: Alehno, I.; Buka, A. and Čevers, A. u.c. Eiropas Savienības Tiesību īstenošana Latvijā. Alehno, I. (zin. red.). Rīga: Latvijas Vēstnesis, 2003.

Hartley, T. C. The Foundations of European Community Law. 6th Edition. New York: Oxford University Press Inc., 2007.

Herzog, R. and Gerken, L. Stop the European Court of Justice. Opinion. 10.09.2008 [interactive]. [accessed on 04-08-2012]. $<$ http://euobserver.com/opinion/26714>.

House of Lords. Constitution Committee. European Union (Amendment) Bill and the Lisbon Treaty: Implications for the UK Constitution. 6th Report of Session 2007-08. London: The Stationery Office Limited, 2008 [interactive]. [accessed on 01-09-2012]. <http://www.publications. parliament.uk/pa/ld200708/1dselect/ ldconst/84/84.pdf $>$. 
Iljjanova, D. Vispārējo Tiesību Principu Nozīme un Piemērošana. Rīga: Ratio Iuris, 2005.

Jelāgins, J. Tiesību Pamatavoti. In: Mūsdienu Tiesību Teorijas Atzinas: Mācību Grāmata / Rakstu Krājums. Mel̦ksisis, E. (red.). Rīga: Tiesu Namu Aǵentūra, 1999.

Joined Cases 28/62, 29/62 and 30/62 Da Costa en Schaake NV, Jacob Meijer NV, HoechstHolland NV v. Netherlands Inland Revenue Administration [1963] ECR 00031.

Joined Cases C-46/93 and C-48/93 Brasserie du Pêcheur SA v. Bundesrepublik Deutschland and The Queen v. Secretary of State for Transport, ex parte: Factortame Ltd and others [1996] ECR I-01029.

Joined Cases C-6/90 and C-9/90 Andrea Francovich and Danila Bonifaci and others v. Italian Republic [1991] ECR I-05357.

Judgement of 14 October 2009 given by the DCC of the Senate in the Case No. SKC899. [interactive]. [accessed on 2908-2012]. <http://www.at.gov.lv/files/ archive/department1/2009/899-09.doc>.

Judgement of 5 March 2009 given by the DAC of the Senate in the Case No. A42347606, SKA-175/2009. [interactive]. [accessed on 14-08-2012]. <www.at.gov.lv/files/docs/ dupate_majas\%20lapai_senaats_2009.doc>.

Judgement of 9 June 2011 given by the Administrative Regional Court in the Case No. AA43-2511-11/14, unpublished.

Kalniņš, E. Tiesību Normu Piemērošanas Loǵiskā Shēma. In: Juridiskās Metodes Pamati. 11 Soḷi Tiesību Normu Piemērošanā. Mel̦ķisis, E. (zin. red.). Rīga: Latvijas Universitāte, 2003.

Konstitucionālo Tiesību Komisijas 2012 Gada 17 Septembra Viedoklis. Par Latvijas Valsts Konstitucionālajiem Pamatiem un Neaizskaramo Satversmes Kodolu. [interactive]. [accessed on 26-12-2012]. $<$ http://www.president.lv/images/modules/ items/PDF/17092012_Viedoklis_2.pdf $>$.

Kriminālprocesa Likums: The Law of the Republic of Latvia. Latvijas Vēstnesis. 2005, No. 74.
Latvijas Republikas Satversme: The Law of the Republic of Latvia. Latvijas Vèstnesis. 1993, No. 43.

Latvijas Republikas Tieslietu Ministrija. Eiropas Savienības Tiesību Ieviešanas Rokasgrāmata. 2008 [interactive]. [accessed on 08-08-2012]. <http://www.tm.gov.lv/lv/ daliba_es/es_ta/tm_kompetence.html $>$.

Levits, E. Eiropas Savienības Tiesības un Satversme. In: Eiropas Tiesības. Otrais Papildinātais Izdevums. Jundzis, T. (red.). Rīga: Juridiskā Koledža, 2007.

Levits, E. Judikatūra - Pamati, Problēmas, Piemērošana. Latvijas Republikas Augstākās Tiesas Biļetens. 2010, 1.

Lutere-Timmele, D. L. Priekšvārds. In: Eiropas Savienības Tiesību Piemērošana. Rokasgrāmata Praktizējošiem Juristiem. Otrais Papildinātais Izdevums. LutereTimmele, D. L. (zin. red.). Rīga: Tiesu Namu Aǵentūra, 2008.

Marchenko, M. N. Sudebnoe Pravotvorchestvo i Sudeiskoe Pravo. Moskva: Prospekt, 2008.

Meḷksisis, E. Tiesību Normu Iztulkošana. In: Juridiskās Metodes Pamati. 11 Soḷi Tiesību Normu Piemērošanā. Meļ̧̧isis, E. (zin. red.). Rīga: Latvijas Universitāte, 2003.

Naômé, C. Le Renvoi Préjudiciel en Droit Européen. Guide Pratique. Bruxelles: De Boeck\&Larcier s.a., 2007.

Neimanis, J. Tiesību Tālākveidošana. Rīga: Latvijas Vēstnesis, 2006.

Nourissat, C. La Jurisprudence de la Cour de Justice des Communautés Européennes: Un Regard Privatiste à Partir de l'Actualité. In: La Création du Droit Par le Juge. Tome 50. Paris: Dalloz, 2007.

Osipova, S. Viduslaiku Tiesību Spogulis. Rīga: Tiesu Namu Aǵentūra, 2004.

Ostrovska, L. Ārējo Normatīvo Tiesību Aktu Hierarhija Pēc Latvijas Pievienošanās Eiropas Savienībai (I). Likums un Tiesības. 2006, 2 (78).

Ostrovska, L. Ārējo Normatīvo Tiesību Aktu Hierarhija Pēc Latvijas Pievienošanās Eiropas Savien̄ibai (II). Likums un Tiesības. 2006, 3 (79). 
Par Rīgas teritorijas plānojuma dą̧as 20062018 gadam, kas attiecas uz Rīgas brīvostas teritoriju, atbilstību Latvijas Republikas Satversmes 115 pantam: Judgement of 17 January 2008 of the Constitutional Court in the Case No. 2007-11-03. Latvijas Vēstnesis. 2008, No. 12.

Par Tiesu Varu: The Law of the Republic of Latvia. Latvijas Republikas Augstākās Padomes un Valdības Ziņotājs. 1993, 1.

Pierhuroviča, L. Eiropas Savienības Tiesas Juridiskais Aktīvisms. Jurista Vārds. 2010, 30 (625).

Rezevska, D. Judikatūra Kā Tiesību Avots: Izpratne un Pielietošana. Latvijas Republikas Augstākās Tiesas Biļetens. 2010, 1.

Rezevska, D. Judikatūra Kā Tiesību Avots: Izpratne un Pielietošana. Slides for the international conference dedicated to the 15th anniversary of operation of the Senate and Chambers of the Supreme Court. The Judicature of the Supreme Court and its Role in the Development of Legal Thought in Latvia. [interactive]. [accessed on 0808-2012]. <http://www.at.gov.lv/lv/about/ conferences/judic/>.

Rezevska, D. Tiesiskās Paḷāvības Principa Satura Konkretizācija un Attīstība Judikatūrā. In: Politika un Tiesības. Tiesību un Juridiskās Prakses Ilgtspējīga Attīstība. Rakstu Krājums. Apvienotais Pasaules Latviešu Zinātnieku 3. Kongress un Letonikas 4. Kongress. Rīga: LU Akadēmiskais Apgāds, 2012.
Rules of Procedure of the Court of Justice (consolidated). OJ, 2 July 2010, C 177.

Rules of Procedure of the Court of Justice. OJ, 28 December 1974, Volume 17, L 350.

Slaņke, G. Eiropas Savienības Tiesības Latvijā - Maldugunis Purvā? [interactive]. [accessed on 29-08-2012]. <http://www. ir.lv/2011/11/22/es-tiesibas-latvija-maldugunis-purva>.

Sniedzīte, G. Tiesnešu Tiesību Jēdziens, Evolūcija un Nozīme Latvijas Tiesību Avotu Doktrinna. Doctoral thesis [interactive]. [accessed on 03-08-2012]. <https://luis.lanet. lv/pls/pub/luj.fprnt?1=1\&fn=F372913737/ Ginta\%20Sniedzite\%202010.pdf $>$.

Sweet, A. S. The European Court of Justice. In: The Evolution of EU Law. 2nd Edition. Craig, P. and de Búrca, G. (eds.). New York: Oxford University Press, Inc., 2011.

Treaty establishing the European Community (consolidated). OJ, 29 December 2006, C 321.

Treaty establishing the European Community (consolidated). OJ, 31 August 1992, Volume 35, C 224.

Treaty of Lisbon amending the Treaty on European Union and the Treaty establishing the European Community. OJ 2007 C 306/01.

Treaty on European Union (consolidated). OJ, 30 March 2010, C 83.

Treaty on the Functioning of the European Union (consolidated). OJ, 30 March 2010, C 83.

\title{
EUROPOS SAJUNGOS TEISINGUMO TEISMO PRAKTIKOS PRIVALOMOJI GALIA
}

\author{
Gundega Mikelsone
}

Latvijos universitetas, Latvija

Santrauka. Nuo Deklaracijos dèl Europos Sajungos teisès aktu aukščiausios galios, kuri yra įtrankta i Lisabonos sutartị priemusios tarpvalstybinès konferencijos užbaigimo aktą, 
2009 m. gruodžio 1 d. įsigaliojimo momento EST judikatūros bendroji privalomoji galia yra pripažinta ES pagrindinio teisès aktu leidejo - dalyviu šaliu - politinès valios išraiška. Toks statusas Deklaracija yra suteiktas (faktiškai - akceptuotas) EST sprendimu bendriuosius teises principus pripažistant privalomosiomis teises normomis, t. y. nurodant, kad siu principu laikomasi nepriklausomai nuo to, ar jie yra, ar nera įrašyti kuriame nors ES norminiame teises akte ar sudarymo sutartyse.

ES teisés yra tokios, kokias savo nutarimuose paskelbia EST, interpretacijos büdu apibrëždamas ES rašytiniu teisès normu turinį. Vèliau kuriamos naujos teises normos ir pripažistami negaliojančiais ES istaigu ar dariniu teises aktai. ES teisiu darna ir konsekvencija galima garantuoti tiktai tada, jeigu EST judikatüra kaip privalomas teisès šaltinis taikomas ne tik konkrečioje byloje, kurioje keliamas prejudicinis klausimas, bet visose dalyviu šalyse, kiekvienoje su teises taikymu susijusioje byloje.

Privalomasis teisès šaltinis yra visi, ne tik į EST judikatüra ịtraukti prejudiciniai nutarimai, nes nèra prasmés kelti prejudicini klausima dèl teisés normu interpretacijos, jeigu tai jau pateikta kitos procedüros metu priimtame nutarime. EST kaip ES teisiu vienybes ir konsekvencijos garantas nenumato ǐskirtinès normos interpretacijos tik todel, kad ši norma taikoma kitoje procedūroje priimtame nutarime.

Teisiškai svarbios išvados arba teiseju veiklos normos atitinka visus tris teises normas apibüdinančius požymius. Reiškia, EST teisèju veiklos teisinès normos yra bendrinès, kaip ir ìtrauktosios $i$ ES norminius aktus. Rašytines teisines normos interpretacija (jos rezultatas) nera nauja teises norma, bet yra visuotinai privaloma atitinkamos normos turinio išraiška, nes ES teises norma ir EST atliktas jos vertimas yra nedalomas vienetas. Vadinasi, EST judikatūra yra privalomas teisès šaltinis.

Latvija, kaip ir kitos kontinentines, arba romanu-germanu tiesinès sistemos, šalys, priklauso vadinamosioms rašytiniu teisiu šalims, kuriose nuolatiniais pagrindiniais šaltiniais pripažistami tiktai norminiai teises aktai. Vadinasi, EST judikatūra yra bendrinis nuolatinis papildomas arba subsidiarus teisè šaltinis Latvijos teisès sistemoje. EST nutarimai nera privalomi precedentai (precedentu teisès) dalyviu šaliu teismams, jiems yra privalomos EST teisiškai svarbios išvados.

Reikšminiai žodžiai: Europos Sajungos Teisingumo teismas, teismo precedentas, teiseju kuriama teisè, teisés šaltinis, interpretavimas, teisèküra.

Gundega Mikelsone, Latvijos universiteto Teisès fakulteto Teisès teorijos ir istorijos katedros doktorantė, prisiekusiųų advokatų biuro „Centrs“ teisininkè. Mokslinių tyrimų kryptys: teisių teorija, judikatūra.

Gundega Mikelsone, Doctoral student in University of Latvia, Faculty of Law, Chair of Legal Theory and History, lawyer in advocate office „Centrs“. Research interests: legal theory, case law. 